\title{
SOBRE A FILOSOFIA DO SENSO COMUM
}

\author{
BENTO PRADO JR.
}

1. O porta-voz do senso comum afirma que o idealismo é sintoma de esquizofrenia. Mas sua crítica da filosofia só vale o que vale sua "psicologia" implícita.

2. A esquizofrenia é cegueira para o mundo, mas é também a transparência (lucidez) do inconsciente.

3. Assim como o porta-voz do senso comum localiza facilmente a esquizofrenia, o esquizofrênico le imediatamente o que está escondido: devolve a palavra ao inconsciente que se quer silenciar. (Pode-se simular a loucura, enganando os especilistas da doença mental; mas, em pleno asilo, diante do simulador, o esquizofrênico pergunta: - que faz você aqui?).

4. Ao fazer a "filosofia" do senso comum, seu porta-voz transforma o punctum caecum que dormia no coração da visão (aquele mínimo de sombra indispensável à visibilidade) em cegueira literal. A errância degenera em erro.

5. O que sabe o esquizofrênico? Que, antes do mundo, comum nos é o desejo. O nós a que se reporta é mais antigo do que aquele que se enuncia como pronome pessoal.

6. A filosofia do senso comum recalca, exatamente como a Metafísica que pretende suprimir. Como ela, pretende fundar a comunidade, radicá-la no solo da Verdade: - Hybris.

7. A filosofia do senso comum ignora a natureza do gosto. Mais do que isso, nasce como a irrupção do mau gosto na filosofia.

8. Para uma psicanálise de filosofia do senso comum: Hegel dizia, a propósito da filosofia crítica, que o medo do erro exprim/e um mais fundo medo da verdade. Que temor se exprime na reatividade da filosofia do senso comum? Esse horror pela esquizofrenia não é, ele próprio, paranóico?

9. A tese muda da paranóia pode ser enunciada nos seguintes termos: Es gibt keine Interpretation, nur Tatsachen. A interpretação delirante é 
cega para seu trabalho interpretado e só quer saber de coisas, boas ou más. 10. A filosofia do senso comum quer que pensemos como de fato pensamos. A questão da filosofia é outra: - por que pensamos assim? Mais precisamente: - por que jä não podemos pensar exatamente assim? 